\title{
Bilateral Absence of Superior Gemellus Muscle in Elderly Cadaver
}

\author{
Ausencia Bilateral del Músculo Gemelo Superior en un Cadáver Anciano
}

Rodrigo M. P. Fernandes; José K. Lazzoli; Jorge H. M. Manaia \& Marcio A. Babinski

FERNANDES, R. M. P.; LAZZOLI, J. K.; MANAIA, J.H. M. \& BABINSKI, M. A. Bilateral absence of superior gemellus muscle in elderly cadaver. Int. J. Morphol., 31(3):902-904, 2013.

SUMMARY: The superior gemellus muscle (SGM) normally arises from the outer surface of the spine of the ischium, blends with the upper part of the tendon of the obturator internus, and is inserted with it into the medial surface of the greater trochanter. In this paper, we describe an anatomical variation in which the SGM is absent bilaterally. Therefore, as there are not many cases in literature, our attention has been drawn to the importance about absence of SGM, in order to improve anatomical and clinical knowledge about this finding.

KEY WORDS: Gross anatomy; Gemellus superior muscle; Anatomical variation.

\section{INTRODUCTION}

The gemelli, obturator internus and quadratus femoris are deep muscles of the hip joint. The Superior Gemellus Muscle (SGM) normally arises from the outer surface of the spine of the ischium, blends with the upper part of the tendon of the Obturator internus, and is inserted with it into the medial surface of the greater trochanter (Hollinshead, 1976; Williams et al., 1989; Moore \& Dalley, 2006).

For Moore \& Dalley, the obturator internus and the superior and inferior gemelli form a tricipital (three-headed) muscle, the triceps coxae (triceps of the hip), which occupies the gap between the piriformis and the quadratus femoris. The common tendon of these muscles lies horizontally in the buttock as it passes to the greater trochanter of the femur.

The anatomical variations of clinically relevant in the musculature from the gluteal region are uncommon (Windisch et al., 2007). The higher frequency of reports intended variations of the sciatic nerve in respect the origins and relationships with other rotator muscles of the thigh (Windisch et al.; Bergman et al., 1988; Machado et al., 2003; Babinski et al., 2003).

Several comparative anatomical studies have described the quadratus femoris (Cunningham, 1881; Wilson,
1888; Bardeen, 1906), however, few reports introduce the details of the obturator internus and gemelli muscles. Nevertheless, the gemelli muscle varies in size, as well as, the SGM may be small or absent, or may be doubled and may insert into the capsule of the hip joint (Terry, 1942; Hollinshead; Aung et al., 2001). Thus, in this paper, we describe an anatomical variation in which the SGM is absent bilaterally.

\section{CASE REPORT}

The study was carried out according to the Helsinki's statement and was approved from our institutional review board. The human cadaver is from division of Human Anatomy at Department of Morphology of the Fluminense Federal University.

During a regular dissection procedure in the anatomical laboratory from the Federal Fluminense University (Niterói, Rio de Janeiro- Brazil), was found an elderly cadaver (male) with the SGM absent bilaterally (Fig. $1 \mathrm{~A}$ and $\mathrm{B}$ ). On both sides of the pelvis, the sciatic nerve passed beneath piriformis and over obturator internus muscle. 


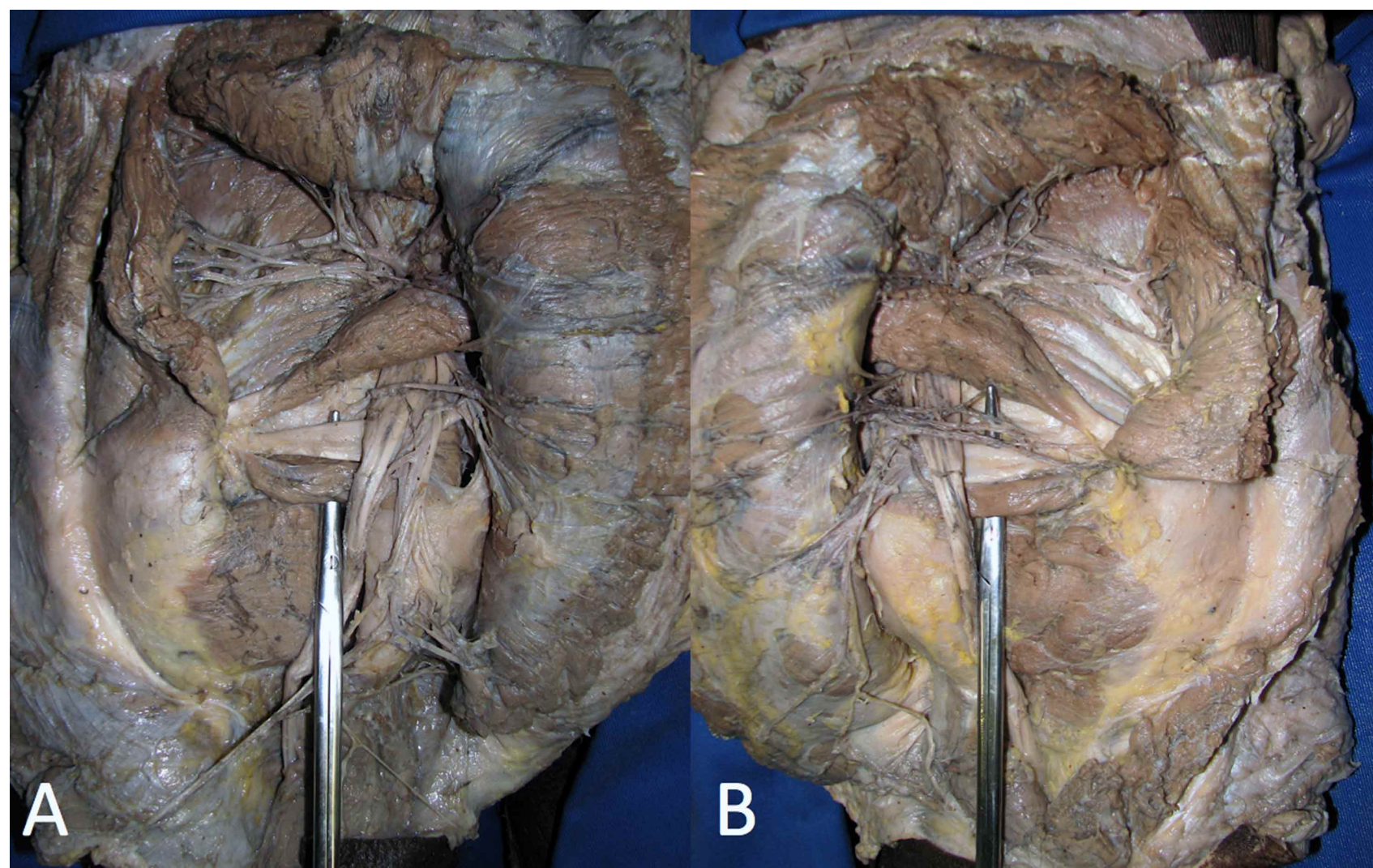

Figure 1. Posterior view of the left gluteal region: A) left side and B) right side. The surgical material passes over the quadratus femoris muscle and beneath internal obturator muscle. Note the bilateral absence of SGM.

\section{DISCUSSION}

The superior gemellus, inferior gemellus, and obturator internus muscles were once regarded as a single muscle judging from their insertion and function. However, current textbooks of anatomy do not treat them as one muscle. In gross anatomy, the classification of muscles depends largely upon the nerve supply (Shinohara, 1995).

Classicals studies of Gräfenberg (1904) and Bardeen, proposed that these muscles are derived from a common muscle anlage, and the obturator internus shifts to the intrapelvic space to cover the obturator foramen. According to these embryological studies, the anlage of the obturator internus and gemelli, even from its earlier stages of differentiation, is distinct in comparison with the quadratus femoris. It is also speculated that the size and proximity (more intimate of obturator internus), the superior gemellus muscle could suffer with the differentiation and be fused as part of the obturator internus fibers projecting into the pelvis.

According to Bergman et al., in very rare cases, both gemelli (superior and inferior) may be absent. The superior gemellus may be fused with piriformis or gluteus minimus, and the inferior gemellus with quadratus femoris (Windisch et al.). Both are frequently, more or less continuous with the obturator internus. Maybe thatexplains the independent agenesis of the SGM bilaterally, as seen in this study.

By other studies, reported that the muscle was absent, on one side or both, in 31 of 254 cadavers (Terry). Wood (1867) described the superior gemellus was absent in 4 of 70 bodies, three men and one woman. Nakano (1922) found no gemelli absent, in Chinese bodies, in 75 body halves. Adachi (1909) could find no case of the superior gemellus being absent in 207 lower limbs of Japanese (Bergman et $a l$.$) .$

In the present paper, we present a rare anatomical variation, where the SGM is absent bilaterally in elderly cadaver. Therefore, as there are not many cases in literature, our attention has been drawn to the importance about absence of SGM, in order to improve anatomical and clinical knowledge about this finding. 
FERNANDES, R. M. P.; LAZZOLI, J. K.; MANAIA, J. H. M. \& BABINSKI, M. A. Ausencia bilateral del músculo gemelo superior en un cadáver anciano. Int. J. Morphol., 31(3):902-904, 2013.

RESUMEN: El músculo gemelo superior (SGM) que se origina de la superficie externa de la parte posterior del isquion, se une a la parte superior del tendón del músculo obturador interno, y se introduce con él en la superficie medial del trocánter mayor. En este trabajo se describe una variación anatómica en la que el SGM está ausente bilateralmente. Debido a la escaza descripción de esta variación, es relevante conocer la ausencia de la SGM, con el fin de mejorar el conocimiento anatómico y clínico de este hallazgo.

PALABRAS CLAVE: Anatomía general; Músculo gemelo superior; Variación anatómica.

\section{REFERENCES}

Adachi, B. Beiträge zur Anatomie der Japanes. Zeitschr. Morphol. Anthropol., 12:261-312, 1909.

Aung, H. H.; Sakamoto, H.; Akita, K. \& Sato, T. Anatomical study of the obturator internus, gemelli and quadratus femoris muscles with special reference to their innervation. Anat. Rec., 263(1):41-52, 2001.

Babinski, M. A.; Machado, F. A. \& Costa, W. S. A rare variation in the high division of the sciatic nerve surrounding the superior gemellus muscle. Eur. J. Morphol., 41(1):41-2, 2003.

Bardeen, R. C. Development and variation of the musculature of the inferior extremity and of the neighboring regions of the trunk in man. Am. J. Anat., 6(1):259-390, 1906.

Bergman, R. A.; Thompson, S. A.; Afifi, A. K. \& Saadeh, F. A. Compendium of human anatomic variation: text, atlas, and world literature. Baltimore, Urban \& Schwarzenberg, 1988.

Cunningham, D. J. The relation of nerve-supply to musclehomology. J. Anat. Physiol., 16(Pt. 1):1-9, 1881.

Gräfenberg, E. Die Entwicklung der menschlichen Beckenmuskulature. Anat. Hefte, 72:429-94, 1904.

Hollinshead, W. H. Functional anatomy of the limbs and back. $4^{\text {th }}$ ed. Philadelphia, Saunders, 1976.

Machado, F. A.; Babinski, M. A.; Brasil, F. B.; Favorito, L. A.; Abidu-Figueiredo, M. \& Costa, M. G. Incidencia de variaciones anatómicas entre el nervio isquiático y musculo piriformis durante el período fetal humano: 10 y 37 semanas póstconcepción. Int. J. Morphol., 21(1):29-35, 2003.

Moore, K. L. \& Dalley, A. F. Clinically Oriented Anatomy. $5^{\text {th }}$ ed. Philadelphia, Lippincott, Williams \& Wilkins, 2006.

Nakano, T. Beiträge zur Anatomie der Chinesen. Okajimas Folio Anat. Jpn., 1:274-82, 1922.

Shinohara, H. Gemelli and obturator internus muscles: different heads of one muscle? Anat. Rec., 243(1):145-50, 1995.
Terry, R. J. Absence of superior gemellus muscle in American Whites and Negros. Am. J. Phys. Anthropol., 29(1):47-56, 1942.

Williams, P.; Warwick, R.; Dyson, M. \& Bannister, L. H. Gray's Anatomy. 37 th $\mathrm{ed}$. London, Churchill Livingstone, 1989.

Wilson, J. T. Abnormal distribution of the nerve to the quadrates femoris in man, with remarks on its significance. J. Anat. Physiol., 23(Pt. 3):354-7, 1888.

Windisch, G.; Braun, E. M. \& Anderhuber, F. Piriformis muscle: clinical anatomy and consideration of the piriformis Syndrome. Surg. Radiol. Anat., 29(1):37-45, 2007.

Wood, J. On human muscular variations in their relation to comparative anatomy. J. Anat. Physiol., 1(1):44-59, 1867.

Correspondence to:

Prof. Dr. Marcio A Babinski

Department of Morphology

Biomedical Center

Fluminense Federal University

Av. Prof. Ernani Mello, 101 São Domingos

CEP 24.210-150

Niterói

Rio de Janeiro

BRAZIL

Fax: (55) (21) 2629-2336.

Email: mababinski@gmail.com

Received: 23-07-2012

Accepted: 14-04-2013 